\title{
Zinc Finger Protein 385B
}

National Cancer Institute

\section{Source}

National Cancer Institute. Zinc Finger Protein 385B. NCI Thesaurus. Code C158574.

Zinc finger protein 385B (471 aa, $\sim 50 \mathrm{kDa}$ ) is encoded by the human ZNF385B gene. This protein may play a role in the regulation of cellular tumor antigen p53 (TP53) signaling pathways. 